\title{
Analisis Morfologi untuk Menangani Out-of- Vocabulary Words pada Part-of-Speech Tagger Bahasa Indonesia Menggunakan Hidden Markov Model
}

\author{
Febyana Ramadhanti ${ }^{1 \#}$, Yudi Wibisono ${ }^{2 \#}$, Rosa Ariani Sukamto ${ }^{3 \#}$ \\ \#Ilmu Komputer, Universitas Pendidikan Indonesia \\ ${ }^{1}$ febyana.ilkomestudent.upi.edu, ${ }^{2}$ yudieupi.edu, ${ }^{3}$ rosa.arianieupi.edu
}

\begin{abstract}
Abstrak-Part-of-speech (PoS) tagger merupakan salah satu task dalam bidang natural language processing (NLP) sebagai proses penandaan kategori kata (part-of-speech) untuk setiap kata pada teks kalimat masukan. Hidden markov model (HMM) merupakan algoritma PoS tagger berbasis probabilistik, sehingga sangat tergantung pada train corpus. Terbatasnya komponen dalam train corpus dan luasnya kata dalam bahasa Indonesia menimbulkan masalah yang disebut out-of-vocabulary (OOV) words. Penelitian ini membandingkan PoS tagger yang menggunakan HMM+AM (analisis morfologi) dan PoS tagger HMM tanpa AM, dengan menggunakan train corpus dan testing corpus yang sama. Testing corpus mengandung 30\% tingkat OOV dari 6.676 token atau 740 kalimat masukan. Hasil yang diperoleh dari sistem HMM saja memiliki akurasi $97.54 \%$, sedangkan sistem HMM dengan metode analisis morfologi memiliki akurasi tertinggi $\mathbf{9 9 . 1 4 \%}$.
\end{abstract}

Kata kunci-Bahasa Indonesia, natural language processing, part-of-speech tagging, hidden markov model, morphological analysis, out-of-vocabulary.

\section{Pendahuluan}

Komunikasi merupakan salah satu hal paling penting yang dibutuhkan manusia sebagai mahluk sosial. Dalam suatu negara, masyarakat umumnya berkomunikasi dengan menggunakan bahasa resmi negara tersebut, seperti bahasa Indonesia. Bahasa Indonesia merupakan bahasa resmi negara Indonesia sebagai identitas bangsa dan lambang kebanggan nasional, yang secara luas dan umum digunakan sebagai alat komunikasi oleh 222 juta orang [1]. Meskipun bahasa Indonesia dituturkan oleh sebagian besar orang di negara tersebut, tetapi ketersediaan alat pemroses bahasa untuk kepentingan penelitian masih terbatas. Sehingga, pengembangan sistem dan penelitian dibidang pemrosesan bahasa alami, khususnya bahasa Indonesia bagi masyarakat luas menjadi penting.

Natural Language Processing (NLP) merupakan suatu pengembangan teknik komputasi bahasa alami dalam menganalisis dan merepresentasikan teks ataupun lisan untuk mencapai pemrosesan bahasa seperti bahasa manusia [2]. Salah satu task dalam bidang NLP yaitu proses pelabelan kata dalam suatu kalimat masukan berdasarkan pada kategori katanya, atau yang disebut dengan part-of-speech (PoS) tagger. Karena pelabelan kelas kata secara manual akan memakan banyak waktu, melelahkan dan dengan biaya yang mahal, sehingga diperlukan pengembangan sistem PoS tagger secara otomatis. Contoh implementasi PoS tagger dalam aplikasi NLP yaitu pada aplikasi seperti grammar checker, speech recognition, question answering dan machine translation [3].

Salah satu metode PoS tagger yang telah dikembangkan [4] yaitu hidden markov model (HMM) dengan pendekatan probabilistic-based sehingga sangat tergantung pada train corpus. HMM merupakan pengembangan dari Markov Model yang mengasumsikan bahwa kata secara probabilistik bergantung pada dua atau lebih kategori kata sebelumnya.

Masalah utama PoS tagger menggunakan HMM disebabkan oleh adanya out-of-vocabulary (OOV) words pada saat proses masukan [5]. OOV merupakan kata yang tidak dikenali kelas katanya oleh sistem, yang disebabkan karena kata tersebut tidak terdapat dalam train corpus tetapi ada dalam testing corpus [6]. Dengan train corpus yang terbatas dibandingkan dengan kata dalam bahasa Indonesia yang sangat banyak, tentu sangat mungkin munculnya OOV words. Diperlukan suatu metode untuk dapat menyelesaikan masalah OOV tersebut.

Salah satu bentuk kata yang paling banyak muncul sebagai OOV dalam bahasa Indonesia yaitu kata yang 
dihasilkan dari proses morfologi yaitu proses pembentukan kata [6]. Proses morfologi yang dimaksud yaitu afiksasi atau proses pembentukan kata yang memiliki imbuhan, seperti kata membantu dengan imbuhan mem- atau berlari dengan imbuhan ber-. Kata yang memiliki imbuhan mem- dan ber- termasuk kedalam kelas kata verba atau kata kerja [7]. Sehingga, imbuhan (afiks) dapat menjadi panduan dalam proses penentuan kelas kata. Berdasarkan panduan tersebut metode analisis morfologi dapat menjadi solusi untuk menangani permasalahan OOV dalam sistem PoS tagger menngunakan HMM.

Penelitian [6] menerapkan tools yang disebut MorpInd [8] dalam menangani OOV. Sedangkan, penelitian ini akan mengembangkan sistem PoS tagger bahasa Indonesia dengan menggunakan $H M M$ dan metode analisis morfologi yang dikembangkan berdasarkan pada aturan morfologi bahasa Indonesia untuk menangani permasalahan OOV.

\section{Peneltian Terkait}

Berbagai metode dan sistem PoS tingging dengan pendekatan rule-based [9], probabilistic-based [10][11] dan transformation-based [12] telah banyak dipublikasikan. Tidak hanya dalam bahasa Indonesia [11], PoS tagger juga telah dikembangkan dalam berbagai bahasa, seperti bahasa Arab [10], bahasa Malaysia [11] dan bahasa India [14].

Wicaksono, dkk [11] menggunakan algoritma Hidden markov model (HMM) untuk PoS tagger dalam kalimat bahasa Indonesia. Masalah utama PoS tagger berbasiskan probabilistik tersebut adalah out-of-vocabulary (OOV) [6][5]. OOV merupakan suatu token yang muncul dalam data uji tetapi tidak terdapat dalam data latih [6].

OOV ditangani [11] menggunakan metode Affix Tree, yaitu suatu metode yang digunakan untuk memperoleh probabilitas emisi pada OOV. Selain itu, OOV juga dapat ditangani menggunakan metode Analisis morfologi (AM) [6]. Metode AM pada [6] mengatasi afiksasi (imbuhan) dengan menggunakan tool Morphind [8] untuk menentukan PoS tag bagi token OOV.

\section{PART-OF-SPEECH (POS) TAGGER}

Part-of-speech (PoS) tagger atau biasa disingkat PoS tagger merupakan salah satu task natural language processing (NLP) dalam proses pelabelan kategori kata (part-of-speech) pada setiap kata dalam teks kalimat masukan terhadap suatu bahasa tertentu [10]. Karena dengan adanya PoS tag maka dapat diketahui bagaimana struktur sintaksis pada keseluruhan kalimat. Sehingga, PoS tagging sangat penting untuk aktivitas syntatic parsing, grammer checker, proses penerjemah bahasa tertentu kebahasa lainnya atau machine translation, hingga dalam memproduksi pelafalan untuk speech recognition [15].
Sebagai contoh implementasi PoS tagging yaitu pada kalimat masukan "Ibu pergi ke pasar .", maka keluarannya akan menjadi Ibu/PRP pergi/VB ke/IN pasar/NN ./Z . PoS tag yang terdapat pada keluaran kalimat tersebut diperoleh berdasarkan tagset pada Tabel I [16].

Ada tiga pendekatan yang digunakan dalam pengembangan PoS tagger yaitu pendekatan probabilistic-based, rule-based dan pendekatan transformation-based [3]. Salah satu algoritma PoS tagger dengan pendekatan probabilistic-based yaitu algoritma Hidden Markov Model (HMM). HMM merupakan pengembangan model statistik dari Markov Model. Dalam Markov Model, menghitung probabilitas setiap kejadian dapat terlihat langsung, dimana setiap busur antar state berisi nilai probabilitas yang dapat mengidentifikasi kemungkinan urutan jalur yang diambil. Tetapi, terkadang ada urutan kejadian yang ingin diketahui tetapi tidak dapat diamati. Oleh karena itu, dikembangkan model baru yang dapat memodelkan kejadian yang tersembunyi (hidden), yaitu Hidden Markov Model. Dalam proses PoS tagging, kejadian atau urutan tag tidak dapat terlihat secara langsung atau tersembunyi (hidden state), tetapi urutan kata yang bergantung terhadap tag tersebut dapat terlihat (observed state).

TABEL I. PART-OF-SPEECH TAGS [16]

\begin{tabular}{|c|l|l|}
\hline No & Tag & \multicolumn{1}{|c|}{ Description } \\
\hline 1. & CC & Coordinating conjunction \\
\hline 2. & CD & Cardinal number \\
\hline 3. & OD & Ordinal number \\
\hline 4. & DT & Determiner / article \\
\hline 5. & FW & Foreign word \\
\hline 6. & IN & Preposition \\
\hline 7. & JJ & Adjective \\
\hline 8. & MD & Modal and auxiliary verb \\
\hline 9. & NEG & Negation \\
\hline 10. & NN & Noun \\
\hline 11. & NNP & Proper noun \\
\hline 12. & NND & $\begin{array}{l}\text { Classifier, partitive and measurement } \\
\text { noun }\end{array}$ \\
\hline 13. & PR & Demonstrative pronoun \\
\hline 14. & PRP & Personal pronoun \\
\hline 15. & RB & Adverb \\
\hline 16. & RP & Particle \\
\hline 17. & SC & Subordinating conjunction \\
\hline 18. & SYM & Symbol \\
\hline 19. & UH & Interjection \\
\hline 20. & VB & Verb \\
\hline 21. & WH & Question \\
\hline 22. & X & Unknown word \\
\hline 23. & Z & Punctuation \\
\hline & & \\
\hline
\end{tabular}


Dalam HMM untuk mendapatkan urutan PoS tag terbaik adalah dengan menggunakan decoding. Tujuan dari HMM decoding adalah memilih urutan tag yang paling mungkin yang berdasarkan pada urutan observased state yaitu $\mathrm{n}$ kata $\left(w_{1}^{n}\right)$ [17]. Adapun persamaan HMM bigram ditunjukan pada persamaan (1),

$$
t_{1}^{n}=\prod_{i=1}^{n} P\left(w_{i} \mid t_{i}\right) P\left(t_{i} \mid t_{i-1}\right)
$$

$$
\begin{aligned}
& \text { dengan } P\left(t_{i} \mid t_{i-1}\right)=\frac{\operatorname{Count}\left(t_{i-1}, t_{i}\right)}{\operatorname{Count}\left(t_{i-1}\right)} \text { dan } P\left(w_{i} \mid t_{i}\right)= \\
& \frac{\operatorname{Count}\left(t_{i}, w_{i}\right)}{\operatorname{Count}\left(t_{i}\right)}
\end{aligned}
$$

Terdapat kasus yang muncul ketika perhitungan probabilitas emisi dan transisi, yang diakibatkan oleh munculnya OOV words. OOV yaitu kata yang tidak dapat ditemukan dalam train corpus, sehingga jumlah dari kata tersebut menjadi nol, sehingga tidak memungkinkan menentukan urutan kelas kata jika nilai probabilitas bigram nol. Untuk menyelesai kasus tersebut [18] menggunakan metode laplace smoothing yang ditunjukan pada persamaan (2),

$$
P\left(w_{i} \mid t_{i}\right)=\frac{\operatorname{Count}\left(t_{i}, w_{i}\right)+1}{\operatorname{Count}\left(t_{i}\right)+|V|}
$$

Dalam bahasa Indonesia, sebuah kata dapat memiliki satu atau lebih kelas kata, sehingga dalam proses decoding, algoritma viterbi merupakan algoritma terbaik dalam menyesaikan masalah tersebut secara cepat (dynamic programming) untuk menentukan PoS tag terbaik, yang ditunjukan pada persamaan (3) [17],

$$
v_{t}(j)=\max _{i=1}^{n} v_{t-1}(i) a_{i j} b_{j}\left(o_{t}\right)
$$

dimana:

$v_{t}(j)=$ probabilitas $\mathrm{HMM}$ state $q_{j}$ pada waktu $t$ setelah melalui observasi,

$v_{t-1}(i)=$ probabilitas viterbi path sebelumnya dari waktu sebelumnya,

$a_{i j}=$ probabilitas transisi dari state $q_{i}$ ke state $q_{j}$,

$b_{j}\left(o_{t}\right)=$ probabilitas emisi dari observasi state $o_{t}$ pada state $j$.

\section{A. Out-of-Vocabulary $(O O V)$}

Masalah yang muncul dalam PoS tagger menggunakan metode hidden markov model disebabkan adanya out-ofvocabulary (OOV) words [5]. Dalam proses PoS tagging berbasiskan probabilistik, out-of-vocabulary words diartikan sebagai kata atau token yang tidak dikenali sebab token tersebut muncul dalam testing corpus tetapi tidak terdapat dalam train corpus [6]

Dalam proses training sistem PoS tagger menggunakan HMM, kata-kata atau token yang merupakan OOV diklasifikasikan sebagai token yang tidak dapat dikenali karena frekuensi dari token tersebut bernilai nol (kosong), sehingga tidak memiliki nilai probabilitas emisi (kosong).

\section{B. Analisis Morfologi (AM)}

Proses morfologi adalah proses pembentukan kata dari sebuah bentuk dasar [7]. Sedangkan analisis morfologi merupakan suatu analisis terhadap proses morfologi itu sendiri, misal proses morfologi pada imbuhan mem- + bantu menjadi membantu, maka analisis morfologi akan menganalisis kata membantu, sehingga dapat diketaui bahwa kata tersebut terdiri dari imbuhan mem- dan kata dasar bantu.

Afiksasi merupakan salah satu proses morfologi pada kata turunan baik berkategori verba (kata kerja), nomina (kata benda) maupun ajektiva (kata sifat) [7]. Afiksasi

\begin{tabular}{|c|c|c|c|}
\hline & \multicolumn{3}{|c|}{ Kategori Kata } \\
\hline & Verba & Nomina & Ajektiva \\
\hline \multirow{20}{*}{$\frac{\mathscr{v}}{4}$} & per- & -nya & se- \\
\hline & -kan & pem- & -an \\
\hline & $-\mathrm{i}$ & pen- & pe- \\
\hline & per-kan & peny- & ter- \\
\hline & per-i & peng- & ke-an \\
\hline & ber-an & penge- & \\
\hline & ber-kan & pe-an & \\
\hline & me-kan & pem-an & \\
\hline & me-i & pen-an & \\
\hline & ke- & peng-an & \\
\hline & ber- & penge-an & \\
\hline & me- & per-an & \\
\hline & mem- & ke- & \\
\hline & men- & ter- & \\
\hline & meny- & se- & \\
\hline & meng- & -an & \\
\hline & menge- & pe- & \\
\hline & di- & ke-an & \\
\hline & ter- & & \\
\hline & ke-an & & \\
\hline
\end{tabular}
dibagi ke dalam tiga kategori yaitu afiksasi pembentuk verba (kata kerja), afiksasi pembentuk nomina (kata benda) dan afiksasi pembentuk ajektiva (kata sifat).

TABEL II. AFIKASi PEMBENTUK Verba, NOMina dAN AJeKTIVA [7] 


\section{HASIL DAN PEMBAHASAN}

Penelitian ini membandingkan dua sistem PoS tagger, yaitu PoS tagger menggunakan HMM saja dan PoS tagger (HMM) yang didukung dengan metode analisis Morfologi.

\section{A. Analisis Data Penelitian}

Analisis dilakukan pada train corpus dan testing corpus sebagai bahan utama penelitian. Train corpus yang digunakan pada penelitian ini berisi kumpulan kalimat bahasa Indonesia yang diperoleh dari penelitian yang telah dilakukan [19], lengkap dengan label kelas katanya yang diberikan secara manual. Data tersebut berisikan 10.026 kalimat atau 261.878 token yang telah dimodifikasi, yaitu dengan mengubah tanda pemisah antar kata dengan tag menjadi vertical line (|), mengubah bentuk data menjadi satu kalimat perbaris, mengubah pemisah antar token dengan spasi dan terakhir menghilangkan bug seperti "|-́́тú".

Testing corpus yang akan digunakan pada penelitian ini, diperoleh dari sumber media massa online. Kemudian data mentah tersebut akan diubah menjadi bentuk satu kalimat perbaris dan dilakukan proses pemilihan hingga menghasilkan 6676 token dengan 1990 OOV atau 30\% tingkat OOV dari data keseluruhan.

TABEL III. JUMLAH OOV SETIAP KELAS KATA PADA TESTING CORPUS

\begin{tabular}{|c|l|c|}
\hline No & \multicolumn{1}{|c|}{ Tag } & Jumlah OOV \\
\hline 1. & CC & 0 \\
\hline 2. & CD & 44 \\
\hline 3. & OD & 0 \\
\hline 4. & DT & 13 \\
\hline 5. & FW & 12 \\
\hline 6. & IN & 65 \\
\hline 7. & JJ & 5 \\
\hline 8. & MD & 0 \\
\hline 9. & NEG & 784 \\
\hline 10. & NN & 418 \\
\hline 11. & NNP & 12 \\
\hline 12. & NND & 4 \\
\hline 13. & PR & 16 \\
\hline 14. & PRP & 0 \\
\hline 15. & RB & 5 \\
\hline 16. & RP & 9 \\
\hline 17. & SC & 0 \\
\hline 18. & SYM & 1 \\
\hline 19. & UH & 582 \\
\hline 20. & VB & 2 \\
\hline 21. & WH & 14 \\
\hline 22. & X & 3 \\
\hline 23. & Z & \\
\hline & & \\
\hline
\end{tabular}

\section{B. Hidden Markov Model (HMM)}

Pada sistem PoS tagger, algoritma hidden markov model merupakan algoritma berbasis probabilistik yang digunakan untuk menentukan tag (kelas kata) terbaik pada setiap kata dalam data testing. Dalam implementasinya, HMM terlebih dahulu masuk pada tahap training, yaitu proses perhitungan terhadap train corpus untuk menghitung nilai probabilitas transisi dan probabilitas emisi yang kemudian nilai-nilai tersebut disimpan. Gambar I menunjukan mekanisme kerja proses training.

Berdasarkan hasil proses training dihasilkanlah 474 macam transisi dan 18.919 macam emisi dengan nilai probabilitasnya masing-masing kemudian disimpan. Nilai-nilai tersebut, kemudian akan menjadi panduan yang digunakan pada saat proses tagging terhadap testing corpus.

Pada proses tagging, sistem akan terlebih dulu melakukan tokenisasi pada kalimat masukan. Kemudian, akan masuk pada tahap perhitungan probabilitas viterbi (forward step) untuk memilih tag terbaik berdasarkan nilai probabilitias viterbi tertinggi. Jika ditemukan token yang merupakan OOV, nilai probabilitas emisinya akan dihitung menggunakan laplace smoothing. Setelah semua token sudah melalui tahap forward, kemudian masuk pada tahap backward untuk pemilihan jalur terbaik.

TABEL IV. HASIL PERHITUNGAN PROBABILITAS TRANSISI DAN EMISI UNTUK KALIMAT "SAYA SEDANG MELIHAT PERTANDINGAN OLAHRAGA."

\begin{tabular}{|c|c|c|c|}
\hline \multirow[b]{2}{*}{$i$} & \multirow[b]{2}{*}{ Kata/token } & \multicolumn{2}{|c|}{$\mathrm{x} 10^{2}$} \\
\hline & & Probabilitas Emisi & $\begin{array}{l}\text { Probabilitas } \\
\text { Transisi }\end{array}$ \\
\hline 0 & Saya & $\begin{array}{l}\text { Saya|PRP = } \\
0.57441847\end{array}$ & $\begin{array}{l}<\text { start }>\text { PRP }= \\
3.9998002\end{array}$ \\
\hline 1 & sedang & $\begin{array}{l}\text { sedang } \mid \mathrm{MD}= \\
0.9704918 \\
\text { sedang } \mid \mathrm{JJ}= \\
0.01471959 \\
\text { sedang } \mid \mathrm{CC}= \\
0.01720578 \\
\text { sedang } \mid \mathrm{SC}= \\
0.0130736\end{array}$ & $\begin{array}{l}\text { PRP MD = } \\
3.213331 \\
P R P ~ J J= \\
0.7620997 \\
P R P C C= \\
0.5061707 \\
\text { PRP SC = } \\
2.0872434\end{array}$ \\
\hline 2 & melihat & $\begin{array}{l}\text { melihat|VB = } \\
0.20140748\end{array}$ & $\begin{array}{l}\mathrm{MD} V \mathrm{VB}=0.268 \\
\mathrm{JJ} \mathrm{VB}=4.322653 \\
\mathrm{CC} \mathrm{VB}= \\
6.7159899 \\
\mathrm{SC} \mathrm{VB}= \\
4.3081884\end{array}$ \\
\hline 3 & pertandingan & $\begin{array}{l}\text { pertandingan } \mid \mathrm{NN}= \\
2.65301249 \mathrm{e}-03\end{array}$ & $\begin{array}{l}\text { VB NN = } \\
27.10233869\end{array}$ \\
\hline 4 & olahraga & $\begin{array}{l}\text { olahraga| } \mathrm{NN}= \\
0.02520361\end{array}$ & $\begin{array}{l}\mathrm{NN} \mid \mathrm{NN}= \\
27.7982649\end{array}$ \\
\hline 5 & $\cdot$ & $\begin{array}{l}. \mid \mathrm{Z}=27.30399845 \\
. \mathrm{NNP}=0.10285995\end{array}$ & $\begin{array}{l}\mathrm{NN} \mid \mathrm{Z}= \\
7.09946143 \\
\mathrm{NN} \mid \mathrm{NNP}= \\
8.2004616\end{array}$ \\
\hline
\end{tabular}


Gambar I menunjukan arsitektur HMM untuk kalimat "Saya sedang melihat pertandingan olahraga ." berdasarkan pada tabel IV.

\section{HMM dan Analisis Morfologi (AM)}

Sama seperti sistem sebelumnya (PoS tagger HMM), sebelum masuk pada proses tagging sistem terlebih dulu melakukan proses training untuk memperoleh nilai probabilitas transisi dan probabilitas emisi.

Pada sistem PoS tagger ini, metode analisis morfologi akan diimplementasikan kedalam proses tagging. Peran analisis morfologi adalah untuk menangani masalah outof-vocabulary (OOV) yang muncul pada saat proses tagging. Token yang merupakan out-of-vocabulary (OOV) nilai probabilitas emisinya akan dihitung menggunakan laplace smoothing.

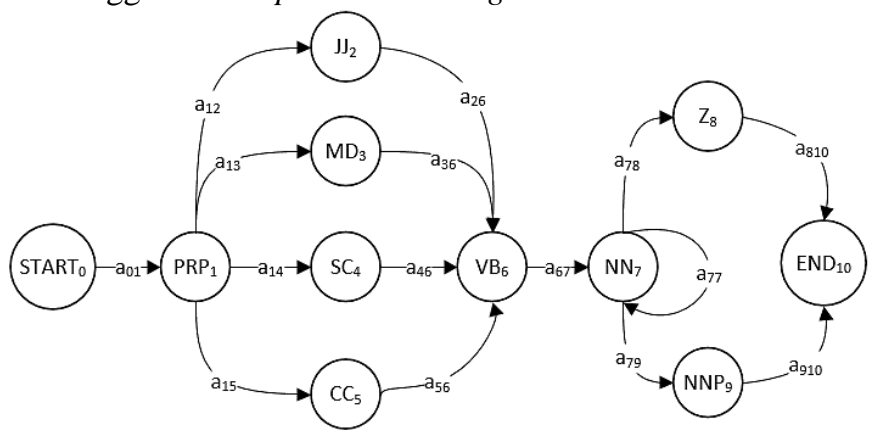

Gambar I. Arsitektur HMM pada kalimat "Saya sedang melihat pertandingan olahraga."

Token OOV yang ditangani oleh metode analisis morfologi adalah token yang miliki imbuhan (afiks). Metode AM mengambil imbuhan token OOV tersebut sebagai acuan dalam menentukan kelas kata, seperti kata pelemparan yang merupakan noun (NN) yang memiliki imbuhan pe-an, dan kata mendamaikan sebagai verb (VB) yang memiliki imbuhan men-kan. Oleh karena itu, berdasarkan ciri-ciri berupa imbuhan tersebut, metode analisis morfologi dapat menangani OOV pada kata yang memiliki imbuhan, sehingga dapat diketahui kelas kata yang tepat. Gambar II menunjukan finite state automata (FSA) metode analisis morfologi (AM) sebagai referensi pada proses AM dalam penentuan tag kelas kata, dengan berbasis aturan atau rule based tanpa menggunakan kamus kata dasar. Serta Gambar III menunjukan mekanisme kerja sistem PoS tagger HMM+AM.

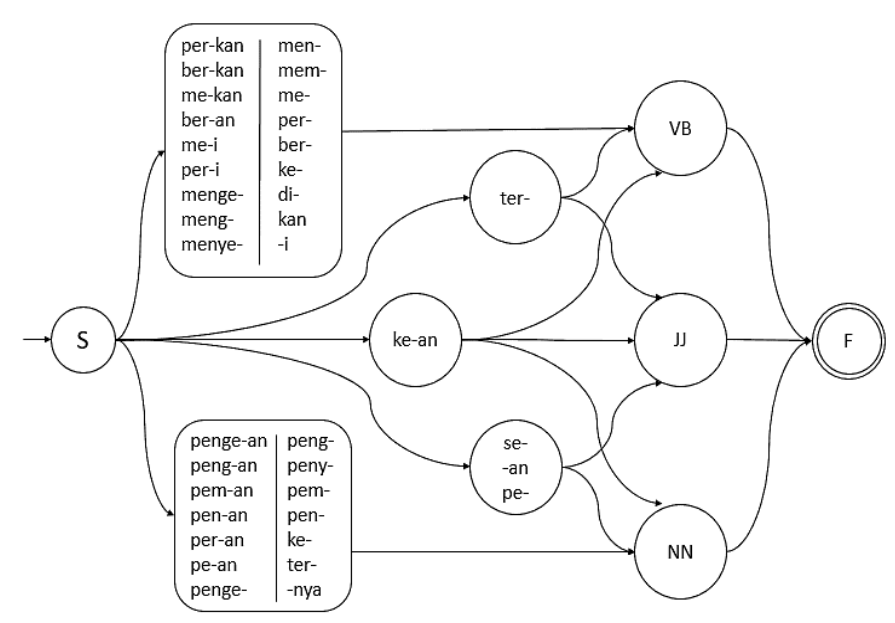

Gambar II. FSA metode analisis morfologi

Berikut ini merupakan langkah-langkah pada proses HMM dan metode AM.

1. Token yang bukan merupakan OOV akan langsung dihitung nilai probalibilitas viterbinya.

2. Token yang merupakan OOV akan diambil kata dasarnya menggunakan modul stemmer yaitu stemmer sastrawi, kemudian kata dasar itu akan dicocokan dengan token yang sebelum di-stemmer, jika berbeda, artinya kata tersebut merupakan kata yang memiliki imbuhan. Hal tersebut dilakukan untuk menghindari pemrosesan AM pada kata dasar yang memiliki ciriciri yang sama dengan imbuhan seperti kata beras (imbuhan ber-), peluit (imbuhan pe-), makan (imbuhan -kan) dan sebagainya.

3. Kata yang memiliki imbuhan akan dipriksa beberapa karakter depan dan/atau karakter belakangnya untuk memperoleh imbuhan kata tersebut, sehingga dapat diketahui kelas katanya. Kata yang hanya memilki satu kemungkinan tag seperti kata dengan imbuhan ber- pada kelas kata verb (VB) dan pem- pada kelas kata noun $(\mathrm{NN})$, akan langsung masuk pada tahap perhitungan probabilitas emisi dan perhitungan probabilitas viterbi. Sedangkan, kata yang memiliki lebih dari satu kemungkinan kelas katanya seperti imbuhan ter- (VB/JJ) akan ditentunkan tag terbaiknya dengan berdasarkan juga pada nilai probabilitas transisinya.

4. Setelah point 1-3 selesai pada semua token dalam kalimat masukan, token-token tersebut akan masuk pada tahap backward (backpointer) untuk menentukan jalur terbaiknya. 


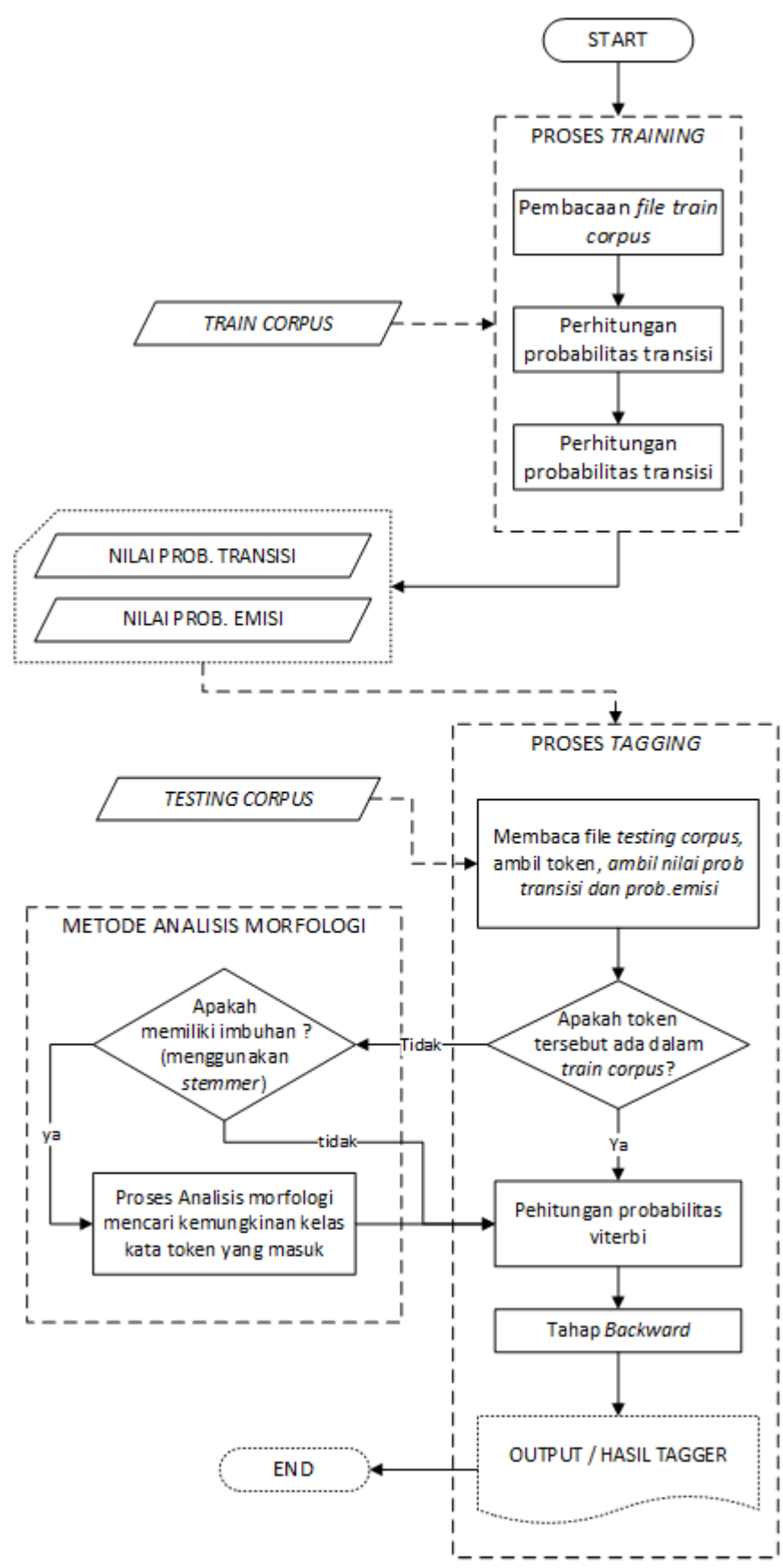

Gambar III. Mekanisme kerja POS tagger menggunakan HMM + AM

\section{Pengujian Sistem}

Evaluasi pada kedua sistem PoS tagger (HMM dan $\mathrm{HMM}+\mathrm{AM}$ ) dilakukan dengan menggunakan train corpus dan testing corpus yang sama.

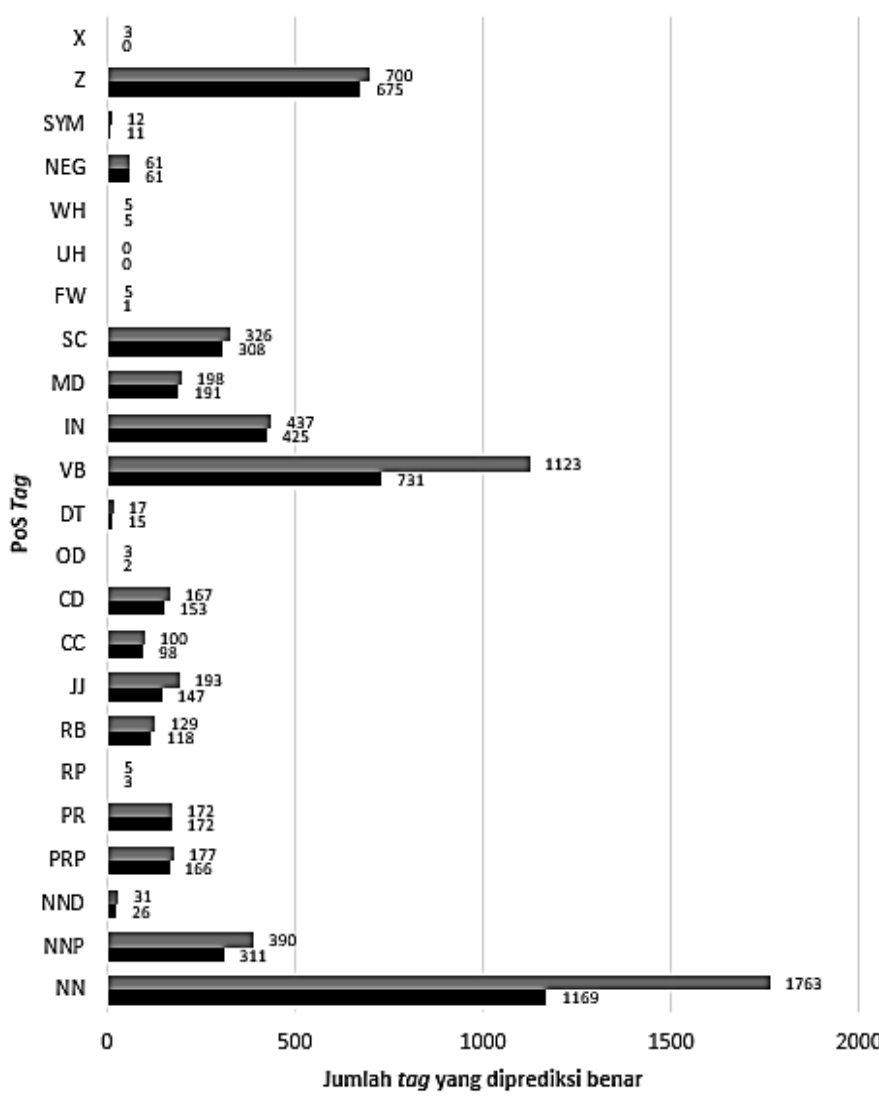

a HMM+AM

Gambar IV. Perbandingan Jumlah tag yang diprediksi benar oleh kedua sistem

Hasil tagging yang diprediksi benar oleh kedua sistem ditunjukan pada Gambar IV. Secara keseluruhan dapat dilihat bahwa PoS tagger dengan menggunakan HMM+AM hampir pada semua PoS tag diprediksi dengan benar lebih banyak dibandingkan dengan PoS tagger menggunakan HMM saja.

Hasil pengujian PoS tagger menggunakan HMM yang disajikan pada Tabel IV menunjukan bahwa sistem tersebut memiliki akurasi $\mathbf{9 7 . 5 4 \%}$. Masih terjadi kesalahan prediksi, yang pada umumnya terjadi pada token yang merupakan OOV. Kesalahan paling dominan terjadi pada tag NN, NNP dan VB. Hal itu terjadi karena dalam testing corpus banyak kata benda, kata kerja dan kata ganti nomina (nama orang, nama tempat).

Pada sistem, token OOV akan diasumsikan dengan semua kemungkin tag (23 tag), sehingga tag pada token tersebut dapat berupa apapun tergantung pada probabilitas viterbi dan pada saat proses backward. Munculnya OOV disebabkan karena komposisi train corpus yang terbatas, sehingga sistem ini sangat tergantung pada komposisi train corpus. 
TABEL IV. HASIL KINERJA POS TAGGER HMM

\begin{tabular}{|c|c|c|c|c|c|}
\hline \multirow{2}{*}{\multicolumn{2}{|c|}{ Confusion Matrix }} & \multicolumn{4}{|c|}{ Ukuran Kinerja } \\
\hline & & Akurasi & Presisi & F-Score & Recall \\
\hline $\mathrm{TP}=4788$ & $\mathrm{FP}=1888$ & & & & \\
\hline $\begin{array}{l}\mathrm{FN}= \\
1888\end{array}$ & $\mathrm{TN}=144984$ & $97,54 \%$ & $71,72 \%$ & $71,72 \%$ & $71,72 \%$ \\
\hline
\end{tabular}

TABEL V. HASIL KINERJA POS TAGGER HMM+AM

\begin{tabular}{|c|c|c|c|c|c|}
\hline \multirow{2}{*}{\multicolumn{2}{|c|}{ Confusion Matrix }} & \multicolumn{4}{|c|}{ Ukuran Kinerja } \\
\hline & & Akurasi & Presisi & F-Score & Recall \\
\hline$T P=6017$ & $F P=659$ & \multirow{2}{*}{$99.14 \%$} & \multirow{2}{*}{$90,13 \%$} & \multirow{2}{*}{$90,13 \%$} & \multirow{2}{*}{$90,13 \%$} \\
\hline $\mathrm{FN}=659$ & $\mathrm{TN}=146213$ & & & & \\
\hline
\end{tabular}

Pada Tabel V, pengujian PoS tagger menggunakan $\mathrm{HMM+AM}$ memiliki akurasi 99.14\%, angka tersebut sudah sangat baik untuk PoS tagger bahasa Indonesia. Dapat dilihat pada Gambar V, prediksi PoS tag dengan benar dibandingkan dengan sistem HMM saja paling dominan terjadi pada tag VB dan NN, hal itu terjadi karena OOV pada sistem kedua ditangani oleh metode analisis morfologi. Walaupun kinerja sistem ini sudah sangat baik, tetapi masih ada kesalahan dalam memprediksi kelas kata. Kesalahan tersebut paling dominan terjadi pada tag NNP (proper noun) yang disebabkan karena token yang merupakan OOV seperti nama orang, nama tempat, nama lembaga dan sebagainya tidak dapat diproses oleh AM. Selain itu, kesalahan prediksi juga terjadi hampir pada semua tag kecuali PRP (personal pronoun), CC (coordinating conjuction), OD (ordinal number), MD (modal and auxiliary verb), NEG (negation), SYM (symbol) dan Z (punctuation). Sama seperti pada point sebelumnya, kesalahan tersebut terjadi karena token-token itu merupakan OOV yang bukan merupakan kata yang memiliki imbuhan, sehingga tidak dapat diproses oleh metode AM.

\section{KESIMPULAN}

Penerapan metode AM pada sistem PoS tagger menggunakan HMM memiliki akurasi lebih baik dibandingkan PoS tagger tanpa AM dalam menangani OOV. Metode analisis morfologi yang dikembangkan belum sepenuhnya efektif karena hanya dapat mengatasi OOV yang memiliki imbuhan saja. Oleh karena itu, dibutuhkan penelitian lebih lanjut untuk mengembangkan metode AM yang dapat mengatasi OOV yang merupakan kata perulangan, kata penyerapan dan mengetahui kelas kata unutk angka, serta proper noun. Secara garis besar, sistem PoS tagger ini juga sangat tergantung pada komposisi train corpus.

\section{REFERENSI}

[1] Lewis, M. P. (2009). Enthnologue: Language of the World, 6th ed., Dallas.

[2] Liddy, E. D. (2001). Natural Language Processing . In Encyclopedia of Library and Information Science, 2nd Ed. NY. Marcel Decker Inc.
[3] Pisceldo, F., Adriani, M., \& Manurung, R. (2009). Probabilistic Part Of Speech Tagging for Bahasa Indonesia. in Proceedings of Third International Wokshop on Malay and Indonesian Language Engineering, Singapore.

[4] Kumar, R., \& Shekhawat, S. S. (2018). Parts Of Speech Tagging For Hindi Languages Using Hmm . International Journal Of Scientific Research.

[5] Brants, T. (2000). Tnt - a Statastical Part-of-Speech Tagger Proceeding of the sixth conference on Applied Natural Language Processing

[6] Muljono, Afini, U., \& Supriyanto, C. (2017). Marphology Analysis for Hidden Markov Model based Indonesian Part-ofSpeech Tagger. 1st International Conference on Informatics and Computational Sciences (ICICoS).

[7] Chaer, A. (2008). Morfologi Bahasa Indonesia. Jakarta: Rineka Cipta.

[8] Larasati, S.D., Kuboň, V. and Zeman, D., 2011, August. Indonesian morphology tool (morphind): Towards an indonesian corpus. In International Workshop on Systems and Frameworks for Computational Morphology (pp. 119-129). Springer, Berlin, Heidelberg.

[9] Alfred, R., Mujat, A. and Obit, J.H., 2013, March. A ruled-based part of speech (RPOS) tagger for Malay text articles. In Asian Conference on Intelligent Information and Database Systems (pp. 50-59). Springer, Berlin, Heidelberg.

[10] Shamsi, F. A., \& Guessoum, A. (2006). A Hidden Markov Model -Based POS Tagger for Arabic. Journées internationales d'Analyse statistique des Données Textuelle.

[11] Wicaksono, A. F., \& Purwarianti, A. (2010). HMM Based Partof-Speech Tagger for Bahasa Indonesia. Proceeding of the Fourth Internationul MALINDO Workshop (MALINDO2010), Jakarta.

[12] Brill, E. (1992). A Simple Rule-Based Part of Speech Tagger. Proceedings of the Third Conference on Applied Computational Linguistics. Trento, Italy: Association of Computational Linguistics.

[13] Alfred, R., Mujat, A., \& Obit, J. H. (2013). A Ruled-Based Part of Speech (RPOS) Tagger for Malay Text Articles. Asian Conference on Intelligent Information and Database Systems.

[14] Joshi, N., Darbari, H., \& Mathur, I. (2013). HMM BASED POS TAGGER FOR HIND. Proceeding of 2013 International Conference on Artificial Intelligence, Soft Computing.

[15] Manurung, R. (2016). Tutorial: Pengenalan terhadap POS Tagging dan Probabilistic Parsing. Workshop Nasional INACL. Depok: Fakultas Ilmu Komputer Universitas Indonesia.

[16] Dinakaramani, A., Rashel, F., Luthfi, A., \& Manurung, R. (2014). Designing an Indonesian Part of Speech Tagset and Manually Tagged Indonesian Corpus. In Asian Language Processing (IALP), Kuching.

[17] Jurafsky, D., \& Martin, J. H. (2014). Speech and Language Processing. Vol. 3. London: Pearson.

[18] Kikuchi, M., Yoshida, M., Okabe, M., \& Umemura, K. (2015). Confidence Interval of Probability Estimator of Laplace Smoothing. Institute of Electrical and Electronics Engineers.

[19] Rashel, F., Luthfi, A., Dinakaramani, A., \& Manurung, R. (2014). Building an Indonesian Rule-Based Part-of-Speech Tagger. Asian Language Processing (IALP), 2014 International Conference on. IEEE. 